Sciendo Порівняльна професійна педагогіка 9(3)/2019 Comparative Professional Pedagogy 9(3)/2019

DOI: $10.2478 /$ rpp-2019-0027

PhD in Pedagogy, Associate Professor, TETIANA HOROKHIVSKA The Institute of Law and Psychology of the National University "Lviv Polytechnic" Address: 12 Stepan Bandera St., Lviv, 79000, Ukraine

E-mail: t.gorohivska@gmail.com

\title{
CHARACTERISTICS OF DEVELOPING PROFESSIONAL-PEDAGOGICAL COMPETENCY IN UNIVERSITY TEACHERS IN THE CONTEXT OF POLISH EXPERIENCE
}

\begin{abstract}
The article deals with the trends in the development of professional-pedagogical competency of university teachers in the Higher Education Area of the EU. It is emphasized that the creation of a global international educational environment requires a holistic technological strategy, whose primary tasks include analyzing the international educational space, standardizing technologies for professional development. The article also clarifies the concept of professional competency based on the analysis of international documents and activities of international organizations (The International Board of Standards for Training, Performance and Instruction; Die Internationale Gesselschaft fur Ingenieur Pedagogik; Standards and Guidelines for Quality Assurance in the European Higher Education Area, etc.). Specific attention is paid to the theoretical analysis of trends in the development of professional-pedagogical competency of university teachers in the context of the Polish experience. Various approaches of Polish scholars, practitioners and university teachers to defining the nature and content of competencies and competences are described (K. Denek, P. Kwolik, E. Wilczkowski, et al.). It is found that the study of teachers' professional competency is an important scientific issue. In Poland, there is still no single approach to understanding the competences, whose formation and development are necessary for developing professional-pedagogical competency in university teachers in the context of higher education reforms (J. Bugaj, A. Kotusiewicz, R. Kwaśnica, N. Kwiatkowska, A. Sajdak et al.). It is determined that the professional development of university teachers in the Republic of Poland, aimed at improving their professional-pedagogical competency, involves a system of professional retraining and advanced training, which are implemented under the conditions of both relevant educational institutions (universities) and directly in the field. It is concluded that the process of developing professional-pedagogical competency in Poland is considered as a complex multidimensional phenomenon, which ensures the continuing personal and professional growth and is an important component of the system of continuing education.
\end{abstract}

Keywords: competency-based approach, professional-pedagogical competency, professional development, university teacher, teacher education, professional training, the European Union, the Republic of Poland.

\section{АНОТАЦІЯ}

У статті розглянуто тендениії розвитку професійно-педагогічної компетентності викладачів у науково-освітньому просторі Свропейського Союзу. Наголошено, що створення глобального міжнародного освітнього середовища вимагає иілісної технологічної стратегії, першорядними завданнями якої $\epsilon$ аналіз міжнародного 
sciendo Порівняльна професійна педагогіка 9(3)/2019 Comparative Professional Pedagogy 9(3)/2019

освітнього простору, стандартизація технологій підвищення професійної компетентності. На основі аналізу міжнародних документів та діяльності міжнародних організацій (International Board of Standards for Training, Performance and Instruction, Die Internationale Gesselschaft fur Ingenieur Pedagogik, "Standards and Guidelines for Quality Assurance in the European Higher Education Area» тощо) опрацьовано проблему визначення природи професійної компетентності особи. Окрему увагу приділено теоретичному аналізу тендениій розвитку професійно-педагогічної компетентності викладачів вищої школи в контексті досвіду Республіки Польща. Охарактеризовано різноманітні підходи польських науковців, педагогів-практиків до визначення сутності та змісту компетентностей та компетенцій (Е. Вільчковський, K. Denek, P. Kwolik та ін.). З'ясовано, щзо дослідження професійної компетентності педагогів відноситься до важливої наукової проблематики. Зауважено відсутність серед науковиів Республіки Польща єдиного підходу до розуміння компетентностей, формування $i$ розвиток яких є необхідним для становлення професійно-педагогічної компетентності викладачів в умовах реформи вищої освіти (J. Bugaj, A. Kotusiewicz, R. Kwaśnica, H. Kwiatkowska, A. Sajdak та ін.). Визначено, щуо професійний розвиток викладачів вищої школи Республіки Польща, спрямований на підвищення рівня їх професійнопедагогічної компетентності, передбачає систему професійної перепідготовки, підвищення кваліфікації реалізується в умовах як спеціально визначених навчальних закладів (університетів, вищих шкіл), так $і$ безпосередньо на місиях педагогічної діяльності. Зроблено висновок про те, що процес розвитку професійно-педагогічноі компетентності польських викладачів розглядається як складне багатовимірне явище, передбачає неперервне особистісне $i$ професійне зростання, виступає важливим компонентом системи неперервної освіти.

Ключові слова: компетентнісний підхід, професійно-педагогічна компетентність, професійний розвиток, викладач вищої школи, педагогічна освіта, професійнопедагогічна підготовка, Європейський Союз, Республіка Польща.

\section{INTRODUCTION}

The strategic area of higher education reforms in Ukraine implies forming new generation teachers, who can professionally implement the state education policy, are initiative and creative at the level of world standards, are willing to generate innovative ideas and strive for continuing professional development, are eager to develop their professional-pedagogical competency. Given the importance of these objectives, it is essential to study and take into account the examples of foreign experience in enhancing the professional competency of educators. One should pay considerable attention to the experience of the Republic of Poland, which has become a Member State of the European Union and occupies a geopolitical position close to Ukraine and maintains close cultural and historical ties with it.

\section{THE AIM OF THE STUDY}

The article aims to theoretically analyze the trends in the development of professionalpedagogical competency in university teachers in the context of the Polish experience.

\section{THEORETICAL FRAMEWORK AND RESEARCH METHODS}

Much attention is paid to the professional development of professionals in the international documents of the European Commission, the UN, UNESCO ("Living and learning for a viable future: the power of adult learning" (CONFINTEA VI, 2009), "Continuing adult education" (OECD, 2012), "Lifelong learning. Policies and strategies" 
"(UNESCO, 2014), "Standards and guidelines for quality assurance in the European Higher Education Area" (2015), etc.), as well as the documents of the Republic of Poland which justify a comprehensive reforming of the education system, including higher education ("Strategia rozwoju szkolnictwa wyższego by 2020"; "Diagnoza stanu szkolnictwa wyższegogo w Polsce (2009) etc.). The Polish experience in providing professionalpedagogical training of university teachers and enhancing professional skills of educators was studied by such Ukrainian scholars as I. Androshchuk (2018), Yu. Hryshchuk, T. Krystopchuk (2013), V. Pavlenko (2015), M. Palchuk (2011) et al. Various aspects of teacher training were also covered by Polish scholars. Thus, the studies of E. Laska (2007), T. Lewowitzki (2011), R. Piwowarski (2001) and others are devoted to the problem of teachers' professional development and creation of standards for professional training. The organization of teacher education and advanced training were analyzed by K. Denek (1998), Cz. Kupisiewicz (1999), R. Pachocinski (2000) et al. The essence of competencybased teacher training was clarified by J. Kuzma (2000), P. Kwolik (2003), J. Pasicznik, E. Wilczkowski (2010), A. Wilczkowska (2010) et al. The development of teachers' professional competency was explored by J. Bugaj (2016), A. Kotusiewicz (1997) et al.

Research methods include descriptive (to study, analyze and characterize documents and scientific-pedagogical sources) and comparative methods (to establish common and different pedagogical patterns) were used.

\section{RESULTS}

Today, the educational systems of foreign countries are characterized by the standardization of the educational process, which correlates with globalization processes and, at the same time, the need to improve professional skills of university teachers (Ovcharuk, 2003). The experts of the International Board of Standards for Training, Performance and Instruction establish the nature of professional competency as one's ability to be professionally responsible and qualified based on the performance of certain functions, which imply achieving certain standards in a particular professional field through applying professional knowledge and skills (International Board of Standards, 2019).

The experts from the DeSeCo Project (Definition and Selection of Competencies: Theoretical and Conceptual Foundations), implemented in 1997 by the representatives of various industries (both national and international organizations, sociologists, economists, employers, educators, policy analysts, etc.) to monitor the quality of education and its compliance with the requirements of society, interpret the concept of competency not simply as some knowledge and abilities but as the possibility to use psychosocial resources (including abilities and skills) under specific living conditions (OECD, 2005, p. 4).

Today, both globalization and modernization are the leading trends in the development of education. Creating a global international educational environment requires a coherent technological strategy (Sysoieva, 2008, p. 183), whose primary tasks include analyzing the international educational space and standardizing technologies for professional development. Nowadays, such an example is demonstrated by the International Society for Engineering Pedagogy (Die Internationale Gesselschaft fur Ingenieur Pedagogik, hereinafter "IGIP"), established in Austria in 1972 at the University of Klagenfurt. As an Associate Member of UNESCO, IGIP has developed a special document which outlines the qualification requirements intended for teachers in higher engineering institutions. It must be noted that this organization aims to provide consistent professional and pedagogical training for teachers of technical subjects at the Centers of Engineering Pedagogy through the introduction of engineering teacher education (advanced training) and the international 
Sciendo Порівняльна професійна педагогіка 9(3)/2019

Comparative Professional Pedagogy 9(3)/2019

exchange of experience and professional knowledge. If a teacher of technical subjects wishes to be awarded the title ING.PAED.IGIP (International Educational Engineer), he/she must be trained under a special programme (at least 204 academic hours), whose educational content should include engineering pedagogy, engineering teacher placement, teaching technologies, laboratory didactic, stylistics, rhetoric, communication and discussions, special sections of psychology and sociology, biological principles of human development, law, management, etc. (Alekseeva, \& Shablygina, 2003, pp. 42-43).

In Ukraine, the Centre for Training and Advanced Training of Teachers from Technical Higher Education Institutions under the system of IGIP has been operating at the Ukrainian Engineering and Pedagogical Academy since 2000. The subjects provided by the IGIP programme are grouped into three stages: psycho-pedagogical and cultural-ethical training; computer technologies of training and intellectual activities; language communication in education. At the same time, the training load is allocated 720 hours, including 288 hours of classroom training. The title ING.PAED.IGIP is confirmed by a relevant certificate.

In this context, one should pay specific attention to the Center Europeen de Developpement et Evaluation de la Formation Professionelle (The European Centre for the Development of Vocational Education), established in 1975 to implement European policy in the field of vocational education. As an agency of the European Union, headquartered in Thessaloniki, Greece, the CEDEFOR assists in the development of vocational training, professional development and advanced training and introduces a system of vocational training common to the Member States.

Also one should consider the updated "Standards and Guidelines for Quality Assurance in the European Higher Education Area", approved at the 2015 Ministerial Conference in Yerevan. The ESG is a set of standards for external and internal quality assurance systems in higher education aimed at promoting a better understanding of the quality of teaching and learning in 47 European countries. The factors in the procedure of internal assurance of higher education quality included the teaching staff, whose role is most important "in creating a high-quality student experience" (Standards and Guidelines, 2015, p. 13).

Still, it must be borne in mind that according to the International Standard Classification of Education (hereinafter "ISCED") (UNESCO, 1997), the modern teacher must meet the following requirements:

- to apply specific knowledge to evaluate, synthesize and critically analyze new ideas and concepts in the relevant professional field;

- to broaden the understanding and awareness of existing knowledge and practical skills within the relevant professional field;

to be able to conduct research, develop, implement and adapt projects aimed at gaining new knowledge and accordingly new solutions;

to show independence, initiative, leadership skills in professional and educational activities under the conditions which require solving complex interdependent problems;

to maintain a strong interest in the development of new initial ideas and processes with high quality of their understanding;

- to communicate within the framework of critical dialogue with colleagues;

- to explore and analyze social norms and relationships;

- to think critically, synthesize new, complex ideas and processes and make strategic decisions based on them;

- to demonstrate the experience of collective engagement with the ability to make strategic decisions under complex professional settings. 
Since 2005, the higher education system in Poland has changed the evaluation of university teachers' professional skills. Polish universities have developed relevant strategies, which justify the ways, methods and forms of professional development of university teachers, continuing teacher education. Professional competency, as one of the leading qualities of the modern university teacher under the modernization of Polish reforms on the education system, is paid much attention. Quite often, however, the concepts of competency, competence and professionalism are used synonymously. In the scientific methodological literature, there are no clear and precise interpretations of these definitions, which leads to the lack of terminological clarity and correctness in the scientific discourse.

At the same time, the conducted analysis of the literature shows that there are different approaches to determining the nature and content of competencies (competences) among Polish scholars. Thus, J. Pasicznik, E. Wilczkowski, \& A. Wilczkowska (2010) believe that the main competences of teachers should include moral, communicative, informational, medial, praxeological, cooperative and creative ones. A somewhat different approach is applied by K. Denek. In his work "O nowy ksztalt edukacji", the scholar singles out communicative competences reflecting the linguistic properties of the educational process, praxeological competences demonstrating the teacher's skills in organization, planning and monitoring, creative competences expressing non-standard thinking and innovation in pedagogical activity and, finally, competences of interaction which imply the expressive nature of the teacher's integration procedures (Denek, 1998, p. 49).

P. Kwolik (2003) has established the system of the modern teacher's competences. He believes that it consists of subject-specific, informational, medial, didactic, methodical, cognitive, diagnostic, postulatory, communicative, psychological, assertive, moral, spiritual, creative, interactive, organizational, realizable, praxeological, facilitative competences, as well as lifelong learning skills, monitoring and evaluation skills (Kwolik, 2003, p. 25).

I. Androshchuk (2018) indicates that the development of the university teacher's professional competency in Poland occurs in the system of general, integral, professional competencies based on the principles of their professional development and practical focus of administrative processes. Today, many scholars state that the study of teachers' professional competency is an important scientific issue and needs to be further justified and elaborated (Kotusiewicz, 1997, p. 337). To this end, Polish scholars identify and study the competences, whose formation and development are necessary for developing professional-pedagogical competency of university teachers in the context of higher education reforms.

Thus, J. Bugaj (2016) describes competencies of research staff in his work, titled "Uniwersyteckie strategie rozwoju zawodowego nauczycieli polskich w Polsce":

core competencies (subject-specific knowledge, innovation, creativity, pedagogical competences, methodological knowledge; research competences);

additional competencies for managers and coordinators (the ability to form a team and search for funding);

- supplementary competencies (analytical skills, diligence, communication skills, ethics, information processing, use of research methods (deduction, induction, synthesis), command of foreign languages, etc.) (p. 57).

According to R. Kwaśnica (2007), the main competencies of the university teacher are as follows: moral (capacity for moral reflection); interpretative competencies (forming the basis for a reflective understanding of the world); communication skills (based on feelings, empathetic perception). Didactic competencies are interpreted by the author as a technical tool of the university teacher. 
Sciendo Порівняльна професійна педагогіка 9(3)/2019 Comparative Professional Pedagogy 9(3)/2019

Analyzing the nature of pedagogical activities, N. Kwiatkowska (2008) emphasizes the special importance of intellectual competency for the individual development of the university teacher, which is based on thorough theoretical training. On the other hand, A. Sajdak (2014), agreeing with the importance of theoretical, methodological, scientific and methodological competencies, believes that teaching and research staff should have the capacity for self-improvement and lifelong learning.

However, A. Sajdak (2014) suggests that the competencies of university teachers should be formed into the following five groups: didactic, methodical, systemic, personal and public ones. Personal competencies are basic ones since they are directly related to the teacher's self, his/her personal and professional development.

K. Denek (1998) also highlights the importance of continuing professional training and pedagogical development, as well as the need for advanced training (p. 57). Cz. Kupisiewicz (1999) indicates that teachers' advanced training is the way to their professional development. The factors in professional development include the volume of knowledge, the desire to learn, scientific progress, professional mobility and means of influence (p. 107).

The system of professional retraining and advanced training is realized based on certain postgraduate technologies with multidisciplinary networks of additional training, which function under the conditions of specially designated educational institutions (universities, colleges) (Kupisiewicz, 1999, p. 87) and directly in the field of pedagogical activities with online access to professional training programmes. According to some Polish researchers (Palchuk, 2011, p. 104), the leading principles of teachers' professional development aimed at developing professional-pedagogical competency should include the following: continuity, unity, differentiation, focus on broad-based training with narrowbased one, comprehensive development across a wide range of education, flexibility, scientificity, affordability of education.

\section{CONCLUSIONS}

Theoretical analysis of the trends in the development of professional-pedagogical competency of university teachers in the context of Polish experience has made it possible to argue that, despite the existence of different approaches to determining the nature and content of competencies among Polish researchers, this process is considered as a complex multidimensional phenomenon, predicts continuing personal and professional growth and is an important component of the continuing education system. The development of professional-pedagogical competency of Polish university teachers is determined by a dynamic and meaningful interpersonal process, which results in changes in their intellectual, motivational, emotional, volitional and activity spheres, life and professional positions.

The prospects for further research include elaborating organizational and pedagogical conditions for developing professional-pedagogical competency of university teachers.

\section{REFERENCES}

1. Alekseeva, L., \& Shablygina, N. (2003). Integratsionnye protsessy v obrazovanii i professionalizm prepodavatelei vysshei shkoly. Moskva: NIIVO.

2. Androshchuk, I. M. (2018). Upravlinnia profesiinym rozvytkom vykladachiv kafedr menedzhmentu universytetiv Respubliky Polshchi: systemnyi pidkhid. Lutsk: AKVA PRINT.

3. Bugaj, J. M. (2016). Uniwersyteckie strategie rozwoju zawodowego nauczycieli akademickich w Polsce. Kraków: Wydawnictwo Uniwersytetu Jagiellońskiego. 
$\checkmark$ sciendo Порівняльна професійна педагогіка 9(3)/2019 Comparative Professional Pedagogy 9(3)/2019

4. Denek, K. (1998). O nowy ksztalt edukacji. Torun: Akapit.

5. International Board of Standards for Training, Performance and Instruction (IBSTPI). (2019). Retrieved from https://ibstpi.org/.

6. Kotusiewicz, A. (1997). Myśl pedeutologiczna $i$ działanie nauczyciela. Białystok: Źak.

7. Krystopchuk, T. Ye. (2013). Pedahohichna osvita v Respublitsi Polshcha: struktura ta zmist. Neperervna profesiina osvita za kordonom, 5, 127-134.

8. Kupisiewicz, Cz. (1999). Rzecz o ksztaiceniu. Wybyr rozpraw i artykuiyw. Radom: Wydawnictwo ITE.

9. Kuzma, J. (2000). Nauczyciele przyszlej szkoly. Krakow: Wydawnictwo Naukowe Akademii Pedagogicznej.

10. Kwaśnica, R. (2007). Wprowadzenie do myślenia o nauczycielu. In Z. Kwieciński \& B. Śliwerski (Eds.), Pedagogika (Vol. 2, pp. 312-313). Warszawa: PWN.

11. Kwiatkowska, H. (2008). Pedeutologia. Warszawa: Wydawnictwo Akademickie i Profesjonalne.

12. Kwolik, P. (2003). Kompetencje zawodowe nauczycieli nauczania początkowego w zreformowanej szkołe podstawowej (szkic teoretyczny). In M. T. Michalewska \& P. Kowolik (Eds.), Kompetencje nauczycieli w reformowanej szkote (pp. 19-31). Katowice: Wydawnictwo Uniwersytetu Śląskiego. WURZ.

13. Laska, E. I. (2007). Edukacja nauczycieli wobec przemian szkoly. Rzeszow:

14. Lewowitzki, T. (2011). Profesiina pidhotovka i pratsia vchyteliv. Kyiv: Renata.

15. OECD. (2005). The definition and selection of key competencies. Executive summary (draft). Retrieved from https://www.oecd.org/pisa/35070367.pdf.

16. Ovcharuk, O. (2003). Suchasni tendentsii rozvytku zmistu osvity v zarubizhnykh krainakh. Shliakh osvity, 2, 17-21.

17. Pachocinski, R. (2000). Wspolczesne systemy edukacyjne. Warszawa: Instytut Badan Edukacyjnych.

18. Palchuk, M. (2011). Model profesiinoi osvity i navchannia u Polshchi chetvertyi etap yevropeiskoi intehratsii. Porivnialna profesiina pedahohika, 2, 101-111.

19. Pavlenko, V. V. (2015). Osoblyvosti pidhotovky maibutnoho vchytelia v Respublitsi Polshcha v konteksti polikulturnoho pidkhodu. Problemy osvity, 82, 196-203.

20. Piwowarski, R. (2001). Dziecko - nauczyciel-rodzice. Warszawa: WsiP.

21. Sajdak, A. (2014). Miejsce dydaktyki ogólnej w przygotowaniu pedagogicznym nauczycieli akademickich. In K. Denek, A. Kamińska \& P. Oleśniewicz (Eds.), Od uniwersytetu do starości: aspekty edukacji osób dorostych (pp. 47-58). Sosnowiec: Humanitas.

22. Standards and Guidelines for Quality Assurance in the European Higher Education Area (ESG). (2015). Retrieved from https://enqa.eu/wp-content/uploads/ 2015/11/ESG_2015.pdf.

23. Sysoieva, S. O. (2008). Osvita i osobystist v umovakh postindustrialnoho svitu. Khmelnytskyi: KhHPA.

24. UNESCO. (1997). International Standard Classification of Education 1997. Retrieved from http://www.unesco.org/education/information/nfsunesco/doc/isced_1997.htm.

25. Wilczkowski, E., Wilczkowska, A., \& Pasicznik, J. (2010). Pidhotovka pedahohiv dlia doshkilnykh zakladiv u polskykh vnz u konteksti Bolonskoho protsesu. Vziato z http://vuzlib.com/content/view/263/84/. 